Gut, 1973, 14, 983-987

\title{
Effects of oral magnesium sulphate on colonic motility in patients with the irritable bowel syndrome ${ }^{1}$
}

\author{
R. F. HARVEY AND A. E. READ \\ From the University Department of Medicine, Bristol Royal Infirmary, Bristol
}

SUMMARY Magnesium sulphate, a substance known to cause release of cholecystokinin (CCK) from the small intestinal mucosa, was given by mouth (dose $0 \cdot 1 \mathrm{~g} / \mathrm{kg}$ in $150 \mathrm{ml}$ water) to 20 patients with the irritable bowel syndrome. A rapid increase in colonic segmental motor activity (onset within two to six minutes in most cases) was seen (percentage activity increased from 16.2 to $23.7 \mathrm{P}<0.05$; mean wave amplitude from $7 \cdot 1$ to $9 \cdot 1 \mathrm{~cm} \mathrm{H}_{2} \mathrm{O}, \mathrm{NS}$; motility index from 144 to $259, \mathrm{P}<0.01$ ). This increase was most marked in 10 patients who complained of attacks of abdominal pain after food (16.1 to $29.8 \%, \mathrm{P}<0.01 ; 6.8$ to $9.6 \mathrm{~cm} \mathrm{H}_{2} \mathrm{O}, \mathrm{P}<0.05 ; 135$ to $350, \mathrm{P}<0.05$ ), and after the magnesium sulphate three of these patients experienced an attack of their usual pain. These findings provide further evidence that 'functional' abdominal pain after food may in some cases be related to an exaggerated intestinal motor response to cholecystokinin.

In approximately $40-50 \%$ of patients with recurrent abdominal pain for which no cause can be found ('functional' abdominal pain) the pain is precipitated or made worse by eating (Chaudhary and Truelove, 1962). Connell, Jones, and Rowlands (1965) demonstrated that in such patients colonic motility was often abnormal, with pronounced increases in intracolonic pressure after food. Holdstock, Misiewicz, and Waller (1969) confirmed the finding of abnormally increased colonic motor activity in patients with unexplained abdominal pain, and showed in some cases that the small intestine was similarly affected. The mechanism of this food-related hypermotility and pain has not yet been fully elucidated, but it seems possible that it could be mediated by one of the gastrointestinal hormones, several of which have motor effects on the gastrointestinal tract. Gastrin apparently has little effect on colonic motility (Misiewicz, Waller, and Holdstock, 1969), but fairly marked increases in the motor activity of the colon in normal subjects have been observed after intravenous cholecystokinin (Grossi, Messina, Del Duca, Ricci, and Messini, 1966; Dinoso, Meshkinpour, and Lorber, 1972). Similar changes were found in patients with the irritable bowel syndrome (Harvey and Read, 1973), particularly those with food-

${ }^{1}$ Based on a paper read to the British Society of Gastroenterology on 6th April 1973.

Received for publication 6 September 1973. related pain of the type described by Connell et al (1965), and four of eight such patients developed a typical attack of their usual pain after cholecystokinin, at the same time as markedly increased colonic motor activity was seen. In an attempt to ascertain whether endogenous CCK has a similar action, we have examined the effect on colonic motility of oral magnesium sulphate ( $\mathrm{MgSO}_{4}$ ), a substance which is a powerful stimulus to endogenous cholecystokinin release (Lyon, 1919; Boyden and Birch, 1930; Boyden, Bergh, and Layne, 1943; Harvey, Dowsett, Hartog, and Read, 1973).

\section{Patients and Methods}

Twenty patients with abdominal pain believed to be due to the irritable bowel syndrome were studied after an overnight fast. All were attending a gastroenterology clinic for investigation of abdominal pain, and routine examination and investigations (including sigmoidoscopy, barium studies and blood examinations) had failed to show a cause for their symptoms. Ten patients had food-related pain, and in the other 10 there was no relationship of the pain with eating.

Pressure changes within the sigmoid colon were recorded, as previously described (Harvey and Read, 1973), on a Devices M19 recorder, using miniature $7 \times 10 \mathrm{~mm}$ balloons (Atkinson, Edwards, Honour, and Rowlands, 1957) placed $20-25 \mathrm{~cm}$ from the anus 
through a sigmoidoscope. After the balloons had been placed in position and the sigmoidoscope removed, the patients rested quietly on the couch for at least 60 minutes. They were then given $150 \mathrm{ml}$ of water to drink and 30 minutes later were given magnesium sulphate $(0.1 \mathrm{~g} / \mathrm{kg}$ in $150 \mathrm{ml}$ water $)$ motility being recorded for a further 30 minutes. Motor activity in the 30 minutes after water and after magnesium sulphate was compared with that in the last 30 minutes of the initial fasting period by measuring the percentage duration of pressure waves, their mean amplitude, and a motility index (multiple of the other two indices). Probabilities were calculated by using Student's t test.

\section{Results}

No significant change in colonic motor activity was seen after water (percentage activity 16.2 to 14.2 ; mean amplitude of pressure waves $7 \cdot 1$ to $8 \cdot 3 \mathrm{~cm}$ $\mathrm{H}_{2} \mathrm{O}$, motility index 144 to 133 ), but all parameters measured showed an increase after $\mathrm{MgSO}_{4}$ (see table). The increase was most marked in the 10 patients whose pain was usually precipitated by eating (fig 1).

There was, however, a moderate overlap between the two groups, five of the 10 patients with pain unrelated to food showing increased motility after $\mathrm{MgSO}_{4}$ and two of the group with food-related pain showing no increase. The high value for motility index after $\mathrm{MgSO}_{4}$ in patients with food-related pain was not due merely to the inclusion of one or two particularly high values: even excluding the two highest, the mean value (209) was still greater than that for the patients with pain unrelated to food Neither was the distribution of motility index in this group particularly skewed, five having values above and five below the mean.

The period of increased colonic motility usually began within a very short time of taking the $\mathrm{MgSO}_{4}$ (2-14 minutes in 12 subjects, mean 4.9 minutes), with a fairly abrupt onset of activity, which increased

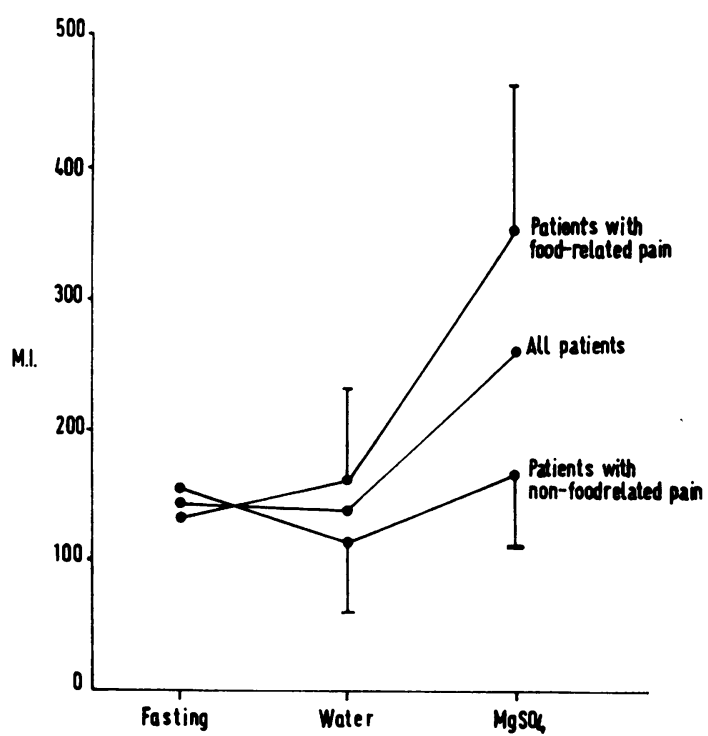

Fig 1 Changes in colonic motility, as motility index (mean and $S E$ ), after water and after $\mathrm{MgSO}_{4}$. Little change occurred after water. After $\mathrm{MgSO}$, the increase in activity was much more marked in the 10 patients with pain after food than in those whose pain was unrelated to eating.

to a peak within a few minutes and in most cases gradually subsided over the course of 20 to 30 minutes (fig 2). In other patients the increase in activity was more marked and more prolonged (fig 3). Three subjects experienced what they described as a typical attack of their usual pain during this period. Others experienced symptoms such as gurgling, 'windy feelings', fulness, belching, and passage of flatus per rectum in the period after $\mathrm{MgSO}_{4}$ was given. There was no detectable quantitative or qualitative difference in motility response between the three patients who experienced pain after $\mathrm{MgSO}_{4}$ and the remainder. In general, motor activity of the rectum was not affected (fig 2).

\begin{tabular}{|c|c|c|c|c|c|c|}
\hline & \multicolumn{2}{|c|}{ Percentage Activity } & \multicolumn{2}{|c|}{$\begin{array}{l}\text { Mean Wave Amplitude } \\
\left(\mathrm{cm} \mathrm{H}_{2} \mathrm{O}\right)\end{array}$} & \multicolumn{2}{|c|}{ Motility Index } \\
\hline & Fasting & After $\mathrm{MgSO}_{4}$ & Fasting & After $\mathrm{MgSO}_{4}$ & Fasting & After MgSO, \\
\hline $\begin{array}{l}\text { All patients } \\
(\mathrm{n}=20)\end{array}$ & $\begin{array}{l}16 \cdot 2 \\
\pm 3 \cdot 0\end{array}$ & $\begin{array}{l}23 \cdot 7^{8} \\
\pm 4 \cdot 1\end{array}$ & $\begin{array}{l}7 \cdot 1 \\
\pm 1 \cdot 1\end{array}$ & $\begin{array}{r}9 \cdot 1^{2} \\
\pm 1 \cdot 9\end{array}$ & $\begin{array}{l}144 \\
\pm 33\end{array}$ & $\begin{array}{l}2594 \\
\pm 65\end{array}$ \\
\hline $\begin{array}{l}\text { Patients with pain not related } \\
\text { to eating }(n=10)\end{array}$ & $\begin{array}{r}16 \cdot 3 \\
\pm 4 \cdot 1\end{array}$ & $\begin{array}{l}17 \cdot 6^{2} \\
\pm 5 \cdot 1\end{array}$ & $\begin{array}{r}7 \cdot 3 \\
\pm 1 \cdot 7\end{array}$ & $\begin{array}{r}8 \cdot 52 \\
\pm 3 \cdot 2\end{array}$ & $\begin{array}{r}153 \\
\pm 41\end{array}$ & $\begin{array}{l}168^{2} \\
\pm 60\end{array}$ \\
\hline $\begin{array}{l}\text { Patients with pain after } \\
\text { eating }(n=10)\end{array}$ & $\begin{array}{r}16 \cdot 1 \\
\pm 4 \cdot 6\end{array}$ & $\begin{array}{l}29 \cdot 84 \\
\pm 6 \cdot 1\end{array}$ & $\begin{array}{r}6.8 \\
\pm 1.4\end{array}$ & $\begin{aligned} & 9 \cdot 6^{8} \\
\pm & 2 \cdot 1\end{aligned}$ & $\begin{array}{r}135 \\
\pm 53\end{array}$ & $\begin{aligned} 350^{2} \\
\pm 112\end{aligned}$ \\
\hline
\end{tabular}

Table Motor activity of the sigmoid colon before and after oral $\mathrm{MgSO}_{4}{ }^{3}$

1 All values $=$ mean $\pm S E M$

${ }^{2}$ N.S. $\quad{ }^{2} \mathrm{P}<0.05 \quad{ }^{2} \mathrm{P}<0.01$ 


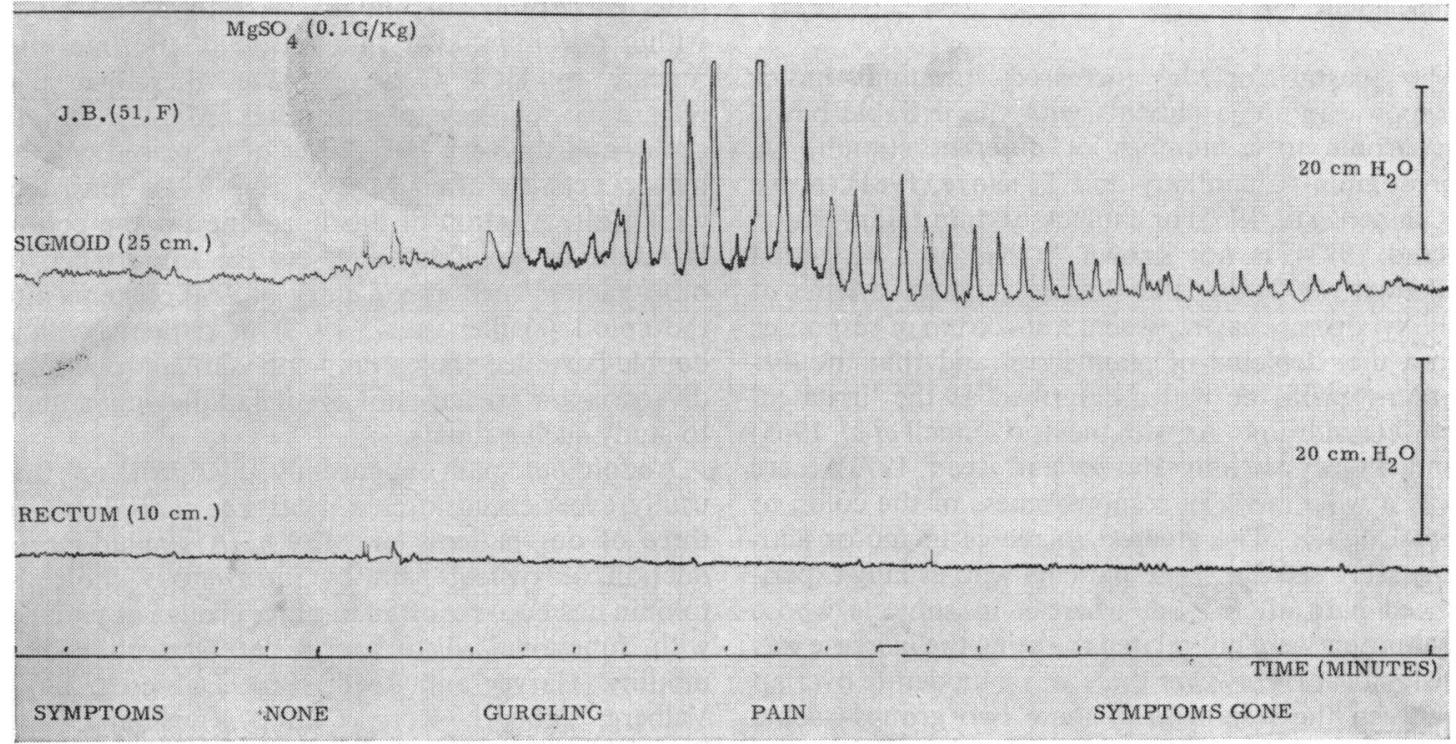

Fig 2 Effect of oral $\mathrm{MgSO}_{4}$ on motor activity of the sigmoid colon and rectum in a woman with unexplained pain after meals. MgSO was given as indicated by the deflections on the upper line. The increase in sigmoid activity was accompanied by pain identical to that typically experienced by the patient after food.

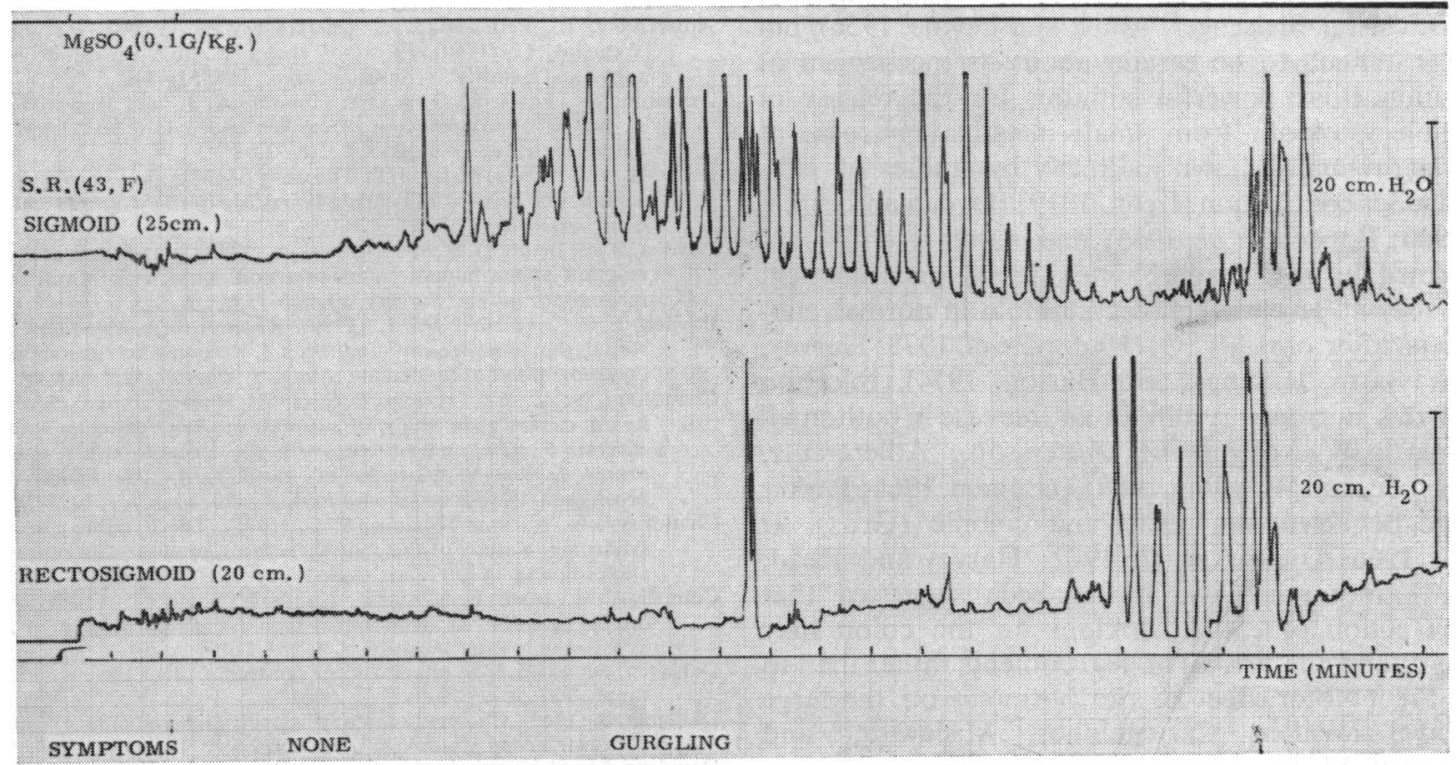

Fig 3 Effect of oral MgSO, on motor activity of the sigmoid colon and rectosigmoid in a 43-year-old woman with food-related pain. The pressure waves are not transmitted to adjacent segments of bowel (waves in the rectosigmoid occur independently of those in the sigmoid) and are thus 'segmenting' rather than peristaltic. Sporadic fast-wave activity can also be seen. 


\section{Discussion}

The reason for the increased intestinal motor response in some patients with the irritable bowel syndrome to a number of different stimuli, eg, prostigmin (Chaudhary and Truelove, 1961), meals (Connell et al, 1965) or cholecystokinin (Harvey and Read, 1973), is not known. It has been suggested (Painter, 1972) that the different clinical varieties of the syndrome may represent a spectrum of responses to a diet depleted of plant fibre, and that the disorders would be better described as the 'irritated' bowel syndrome. As with meals (Connell et al, 1965) and cholecystokinin (Harvey and Read, 1973), there was a wide range of responsiveness of the colon to oral $\mathrm{MgSO}_{4}$. The greatest increases in motor activity were seen in those patients who usually experienced pain after food, whereas in subjects whose symptoms were not related to eating the increase was insignificant. However there was a moderate overlap between the responses in these two groups-some patients with food-related pain showing no increase in motility, whereas some whose symptoms were unrelated to food nevertheless showed increased motility after $\mathrm{MgSO}_{4}$. It seems therefore that these patients do not fall into two clear-cut and distinct groups, but that they represent a spectrum of differing degrees of responsiveness to the stimulus.

Magnesium sulphate has previously been shown to cause an increase in colonic motor activity (Davidson, Sleisenger, Almy, and Levine, 1956), but it is difficult to be certain about its mechanism of action. It is a powerful stimulus for the release of cholecystokinin from small intestinal mucosa, as was originally shown indirectly by studies of gallbladder contraction (Lyon, 1919; Boyden and Birch, 1930; Boyden et al, 1943) and more recently confirmed by direct radioimmunoassay measurement of serum levels of cholecystokinin in normal subjects after oral $\mathrm{MgSO}_{4}$ (Harvey et al, 1973; Harvey, Grayburn, Jennings, and Hartog, 1974). Injection of this hormone results in an increase in both small intestinal (Adlercreutz, Pettersson, Adlercreutz, Gribbe, and Wegelius, 1960; Dahlgren, 1966; Parker and Bene-ventano, 1970) and colonic (Grossi et al, 1966; Dinoso et al, 1972; Harvey and Read, 1973) motor activity. It has been suggested that the action of cholecystokinin on the colon may be due to the arrival of ileal contents rather than to a direct motor effect of the hormone on the large bowel (Waller, Carvalhinhos, Misiewicz, and Russell, 1973).

Studying nine normal male subjects, Boyden et al (1943) showed that gallbladder contraction began on average one to five minutes after intraduodenal instillation of $\mathrm{MgSO}_{4}$. Berry and Flower (1971) detected cholecystokinin release into portal blood within one minute of stimulation of the intestinal mucosa by $\mathrm{HCl}$. It is probable, therefore, that release of cholecystokinin after $\mathrm{MgSO}_{4}$ is very rapid, and the very early onset of increased colonic motor activity after $\mathrm{MgSO}_{4}$ (fig 2) is consistent with a direct action of this hormone on the colon. It might be possible to assess the importance of other factors such as the entry of ileal contents into the colon (Waller et al, 1973) in patients with a double-barrelled colostomy or similar operative diversion, but we have not as yet had the opportunity to study such patients.

Abdominal pain apparently identical to that usully experienced after a meal was reproduced in three of our patients by $\mathrm{MgSO}_{4}$. A similar reproduction of typical pain by intravenous cholecystokinin has been reported in other groups of patients with functional disturbances of gastrointestinal motility (Harvey and Read, 1973; Dahlgren, 1964; Valberg, Jabbari, Kerr, Curtis, Ramchand, and Prentice, 1971). The findings of the present study provide further evidence that the intestinal hypermotility and pain after food in some patients with the irritable bowel syndrome may be due to an exaggerated motor response to endogenous cholecystokinin.

\section{References}

Adlercreutz, E., Pettersson, T., Adlercreutz, H., Gribbe, P., and Wegelius, C. (1960). Effect of cholecystokinin on duodenal tonus and motility. Acta med. Scand., 167, 339-342.

Atkinson, M., Edwards, D. A. W., Honour, A. J., and Rowlands, E. N. (1957). Comparison of cardiac and pyloric sphincters: a manometric study. Lancet, 2, 918-922

Berry, H., and Flower, R. J. (1971). The assay of endogenous cholecystokinin and factors influencing its release in the dog and cat. Gastroenterology, 60, 409-420.

Boyden, E. A., Bergh, G. S., and Layne, J. A. (1943). An analysis of the reaction of the human gallbladder and sphincter of Oddi to magnesium sulfate. Surgery, 13, 723-733.

Boyden, E. A., and Birch, C. L. (1930). Reaction of gallbladder to stimulation of gastro-intestinal tract. I. Response to substances injected into the duodenum. Amer. J. Physiol., 92, 287-300.

Chaudhary, N. A., and Truelove, S. C. (1961). Human colonic motility: a comparative study of normal subjects, patients with ulcerative colitis and patients with the irritable colon syndrome. I. Resting patterns of motility. II. The effect of prostigmin. III. Effects of emotions. Gastroenterology, 40, 1-36.

Chaudhary, N. A., and Truelove, S. C. (1962). The irritable colon syndrome: a study of the clinical features, predisposing causes and prognosis in 130 cases. Quart.J. Med., 31, 307-322.

Connell, A. M., Jones, F. A., and Rowlands, E. N. (1965). Motility of the pelvic colon. IV. Abdominal pain associated with colonic hypermotility after meals. Gut, 6, 105-112.

Dahlgren, S. (1964). The afferent loop syndrome. Acta chir. scand., suppl., 327.

Dahlgren, S. (1966). Cholecystokinin: pharmacology and clinical use. Acta chir. scand., Suppl. 357, pp. 256-260.

Davidson, M., Sleisenger, M. H., Almy, T. P., and Levine, S. Z. (1956) Studies of distal colonic motility in children. II. Propulsive activity in diarrhoeal states. Pediatrics, 17, 820-833.

Dinoso, V. P., Meshkinpour, H., and Lorber, S. H. (1972). The response of the sigmoid colon and rectum to exogenous cholecystokinin and secretin. Gastroenterology, 62, 844.

Grossi, F., Messina, B., Del Duca, T., Ricci, M., and Messini, M. 
(1966). Attività peristaltica di massa del colon in seguito a somministrazione di 'cecekin'. Clin. Ter., 37, 117-121.

Harvey, R. F., Dowsett, L., Hartog, M., and Read, A. E. (1973). A radioimmunoassay for cholecystokinin-pancreozymin.Lancet, 2, 826-829

Harvey, R. F., Grayburn, J. A., Jennings, R., and Hartog, M. (1974). Changes in serum insulin and cholecystokinin-pancreozymin after different oral stimuli. (In preparation).

Harvey, R. F., and Read, A. E. (1973). Effect of cholecystokinin on colonic motility and symptoms in patients with the irritable bowel syndrome. Lancet, 1, 1-3.

Holdstock, D. J., Misiewicz, J. J., and Waller, S. L. (1969). Observations on the mechanism of abdominal pain. Gut, 10, 19-31.

Lyon, B. B. V. (1919). Diagnosis and treatment of diseases of the gall-bladder and biliary ducts: preliminary report on a new method. J. Amer. med. Ass., 73, 980-982.
Misiewicz, J. J., Waller, S. L., and Holdstock, D. J. (1969). Gastrointestinal motility and gastric secretion during intravenous infusions of gastrin II. Gut, 10, 723-729.

Painter, N. S. (1972). Irritable or irritated bowel. Brit. med. J., 2, 46.

Parker, J. G., and Beneventano, T. C. (1970). Acceleration of small bowel contrast study by cholecystokinin. Gastroenterology, 58, 679-684.

Valberg, L. S., Jabbari, M., Kerr, J. W., Curtis, A. C., Ramchand, S. and Prentice, R. S. A. (1971). Biliary pain in young women in the absence of gallstones. Gastroenterology, 60, 1020-1026.

Waller, S. L., Carvalhinhos, A., Misiewicz, J. J., and Russell, R. I (1973). Effect of cholecystokinin on colonic motility. Lancet, $1,264$.

\section{The November 1973 Issue}

\section{THE NOVEMBER 1973 ISSUE CONTAINS THE FOLLOWING PAPERS}

The Lundh test in the diagnosis of pancreatic disease: A review of five years' experience $A$. MOTTALEB, F. KAPP, E. C. A. NOGUERA, T. D. KELLOCK, H. S. WIGGINS, AND SHEILA L. WALLER

Inhibition by secretin of the gastric acid responses to meals and to pentagastrin in duodenal ulcer patients STANISEAW J. KONTUREK, JERZY BIERNAT, AND TADEUSZ GRZELEC

Amylopectin sulphate (SN-263) coats the gastric mucosal surface D. S. ZIMMON AND VINCENT MAZZOLA

The pepsinogens of human gastric mucosa $D$. $P$. WHITECROSS, C. ARMSTRONG, A. D. CLARKE, AND D. W. PIPER

Gastrin in portal and peripheral venous blood after feeding in man H. DENCKER, R. HÄKANSON, G. LIEDBERG, C. NORRYD, J. OSCARSON, J. F. REHFELD, AND F. STADIL

The interaction of glucagon and pentagastrin on the lower oesophageal sphincter in man and dog $\mathbf{H}$. M. JENNEWEIN, F. WALDECK, R. SIEWERT, F. WEISER, AND R. THIMM

Abscess and fistulae in Crohn's disease DAVID M. STEINBERG, W. TREVOR COOKE, AND J. ALEXANDER-

Secretin cells in coeliac disease JULIA M. POLAK, A. G. E. PEARSE, SUSAN VAN NOORDEN, S. R. BLOOM, AND MARY A. ROSSITER

Lymphoblastic response to autologus colon epithelial cells in ulcerative colitis in vitro P. S. HUNT AND S. TROTTER WILLIAMS

Circulating carcinoembryonic antigen (CEA): Relationship to clinical status of patients with inflammatory bowel disease A. H. RULE, C. GOLESKIREILLY, D. B. SACHAR, J. VANDEVOORDE, AND H. D. JANOWITZ

Bile salt metabolism in patients with gallstones in functioning gallbladders E. W. POMARE AND $\mathrm{K}$. W. HEATON

Disseminated intravascular coagulation associated with hepatitis in late pregnancy C. T. A. JONES, C. R. BIRCH, L. POLLER, AND I. W. DYMOCK

Cholic acid synthesis as an index of the severity of liver disease in man WILLIAM C. MCCORMICK III, $C$. COOPER BELL,JR, LEON SWELL, AND Z. RENO VLAHCEVIC

A new technique for examining intestinal biopsies B. L. CHAPMAN, K. HENRY, F. PAICE, J. S. STEWART, AND N. F. COGHILL

\section{Technique}

The measurement of gastric transmucosal potential difference through a gastroduodenoscope $\mathbf{K}$. $M$. COCHRAN AND R. I. RUSSELL

\section{Progress report}

Chaga's enteropathy J. V. MARTINS CAMPOS AND W. L. TAFURI

\section{British Society for Digestive Endoscopy}

Notes and activities

Copies are still available and may be obtained from the PUBLISHING MANAGER, BRITISH MEDICAL ASSOCIATION, TAVISTOCK SQUARE, LONDON, WC1H 9JR, price 871 $\mathrm{p}$. 